\title{
Managing Selling Coopetition: A Case Study of the ERP industry
}

\author{
Estelle Pellegrin-Boucher, ${ }^{1}$ Frédéric Le Roy ${ }^{1,2}$ and Călin GurăU ${ }^{2}$ \\ ${ }^{1}$ Montpellier Management Institute, University of Montpellier, Montpellier, France \\ ${ }^{2}$ Montpellier Business School, Montpellier, France
}

\begin{abstract}
Managing coopetition is important for the success of coopetition strategies. Past studies on the management of coopetition are largely dedicated to $R \& D$ coopetition. However, selling coopetition is an important phenomenon that is quite different from $R \& D$ coopetition. In this research, we therefore focus on the management of selling coopetition and build on past studies to formalize a framework that combines two complementary principles: separation and integration. We then evaluate the relevance of this framework for managing selling coopetitive agreements by studying how firms from the ERP industry manage their coopetitive selling. The results show that the principles of separation and integration are present but not sufficient to manage selling coopetition. We underline that a third principle, internal arbitration, is a key element in managing selling coopetition. To our knowledge, this is the first study specifically dedicated to the management of selling coopetition.
\end{abstract}

Keywords: coopetition; selling; alliances; management; arbitration; ICT firms

\section{Introduction}

Coopetition strategies allow firms to achieve economies of scale, access strategic resources, and create interorganizational synergies (Gnyawali and Park, 2009, 2011; Yami et al., 2010; Bouncken and Kraus, 2013). However, coopetition strategies can also expose firms to risks, such as loss of secrets and loss of control of their capabilities (Bouncken and Fredrich, 2012; Dagnino et al., 2012; Peng et al., 2012; Ritala, 2012). These risks create tensions inside and between the firms involved in coopetitive strategies. If these tensions are too high and not well controlled, coopetition strategies can fail and damage the participating firms. Therefore, the application of effective management principles and procedures is crucial for the success of coopetitive strategies (Tidström, 2013; Fernandez et al., 2014; Le Roy and Fernandez, 2015; Le Roy and Czakon, 2016).

Different schools of thought are based on relevant principles regarding managing coopetition. The first school of thought recommends organizational separation between competition and cooperation (Dowling et al., 1996; Bengtsson and Kock, 2000; Oliver, 2004; Herzog,

\footnotetext{
Correspondence: Estelle Pellegrin-Boucher, Montpellier Management Institute, 208 Rue Vendémiaire, 34000 Montpellier, France. E-mail estelle.boucher@umontpellier.fr
}

2010). Because people cannot internalize the duality of coopetition, firms must create organizational separation between activities dedicated to competition and activities dedicated to collaboration. In contrast, the second school of thought holds that organizational separation does not address the complex and interdependent nature of coopetition. Scholars thus recommend that employees individually integrate the coopetition paradox (ClarkeHill et al., 2003; Oshri and Weber, 2006; Chen, 2008; Gnyawali and Park, 2011).

The third school of thought suggests that these two principles of separation and integration have their own interests as well as limitations. Therefore, they must be combined to ensure efficient management of coopetition (Fernandez et al., 2014; Fernandez and Chiambaretto, 2016; Seran et al., 2016). Another research stream regards the combination of these two principles as necessary but not sufficient. It is recommended that a third principle be added: the co-management principle (Le Roy and Fernandez, 2015).

This debate on the relevance of coopetition management principles is mainly focused on how to manage collaboration between competitors in $R \& D$ projects. As a general rule, prior research on coopetition has focused on collaboration for innovation (QuintanaGarcía and Benavides-Velasco, 2004; Gnyawali and Park, 2011; Ritala, 2012; Bouncken and Kraus, 2013; Ritala and Sainio, 2014; Estrada et al., 2016). However, 
collaboration with competitors can occur in areas other than R\&D.

Many cooperative agreements between competitors are established in the marketing, distribution and sales fields (Peng and Bourne, 2009; Kylänen and Mariani, 2012, 2014; Pellegrin-Boucher et al., 2013; Chiambaretto and Dumez, 2016; Chiambaretto et al., 2016; Mariani, 2016). Coopetition in selling fields appears to be a particularly important strategy in many industries, such as the airline (Chiambaretto and Dumez, 2016), TIC (Pellegrin-Boucher et al., 2013), and tourism industries (Kylänen and Mariani, 2012, 2014; Czakon and Czernek, 2016).

Despite the importance of coopetition in selling activities, little research has been dedicated to this type of coopetition. In particular, no studies have focused on investigating the management of coopetition in selling activities. To bridge this gap, the present research aims to answer the following questions: What management principles are relevant to managing selling coopetition? Is the separation principle relevant to managing selling coopetition? Is the integration principle relevant to managing selling coopetition? If not, which additional principles should firms use to manage selling coopetition?

To address these questions, we apply a qualitative approach. We investigate the main competitors involved in developing and commercializing enterprise resource planning (ERP) applications: SAP, Oracle and IBM. We study how these firms manage selling coopetition between them. Our results indicate that the firms use the separation principle between sales people in charge of competition and alliance managers in charge of cooperation. Such separation is necessary to resolve coopetitive tensions, but paradoxically, it creates new internal tensions between sales people and alliance managers.

To resolve conflicts due to these tensions, top management helps sales people and alliance managers to cognitively integrate the coopetitive paradox. However, complete integration cannot be achieved, and coopetitive tensions between those involved remain high. Therefore, firms introduce another principle, internal arbitration, enacted by top management. Such arbitration permits temporary conflict resolution. We conclude that the three principles of separation, integration and arbitration together facilitate the management of coopetitive selling agreements.

This research contributes to existing knowledge in several ways. First, this is the first study specifically dedicated to the management of selling coopetition. We formalize a theoretical framework of selling coopetition management and highlight managerial procedures and processes used by firms to manage this type of coopetition. Second, this research contributes to theory on coopetition management. We complement past studies dedicated primarily to $R \& D$ coopetition and identify both common and different principles used for different types of coopetition. Finally, we contribute to coopetition knowledge by showing in detail how coopetition pertains to not only activities far from the market, such as R\&D, but also activities directly linked to the market, such as selling activities.

\section{Theoretical background}

\section{Selling coopetition}

For Brandenburger and Nalebuff (1996), coopetition is a value net involving the focal firms' interplay with customers, suppliers, complementors, and competitors. Bengtsson and Kock (2000) and Gnyawali and Park (2011) adopt a narrow definition in which coopetition is viewed as dyadic interplay between two firms that compete and cooperate with one another simultaneously. For a better understanding of the concept and its implications (Bengtsson and Kock, 1999), we adopt the narrow definition of Gnyawali and Park (2011: 51): 'coopetition is a simultaneous pursuit of collaboration and competition between a pair of firms'. Therefore, coopetition is a counter-intuitive, paradoxical relationship that simultaneously includes competition and cooperation, which are a priori opposite forces (Padula and Dagnino, 2007; Gnyawali and Park, 2011; Bengtsson and Kock, 2000, 2014; Czakon et al., 2014).

Past studies dedicated to coopetition have largely focused on R\&D coopetition for new product innovation (Quintana-García and Benavides-Velasco, 2004; Gnyawali and Park, 2011; Ritala, 2012; Bouncken and Kraus, 2013; Ritala and Sainio, 2014; Estrada et al., 2016; Ritala et al., 2016). Coopetition is viewed as a strategy in which competitors collaborate during upstream stages of the value chain that are far from the client, and compete during downstream stages of the value chain that are close to the client (Bengtsson and Kock, 1999, 2000). The market is the field of competition, and market cooperation should generate suspicion of collusion.

However, competitors do not limit their cooperation to stages far from the market. Many cooperative agreements are established between competitors in activities close to the market, such as marketing, distribution and sales (Peng and Bourne, 2009; Pellegrin-Boucher et al., 2013; Kylänen and Mariani, 2014; Chiambaretto and Dumez, 2016; Chiambaretto et al., 2016; Mariani, 2016). Selling coopetition, in particular, is a growing strategy in industries such as the airplane (Chiambaretto and Dumez, 2016), Information and Communication Technologies (ICT) (Pellegrin-Boucher et al., 2013) and tourism industries (Kylänen and Mariani, 2012, 2014; Czakon and Czernek, 2016). However, this type of coopetition is still under-investigated and needs more research. 
From this perspective, the first step is to define selling coopetition. As a general rule, a selling alliance is a collaboration between firms in sales and distribution activities (Chonko, 1999; Jones et al., 2003). Therefore, selling coopetition should be defined as collaboration between competitors in sales and distribution activities. Selling coopetition can take many forms depending on the industry. For example, in the airline industry, selling coopetition consists of sharing commercial code between competitors to increase the number of routes offered to the client (Chiambaretto and Dumez, 2016). In TIC services, selling coopetition involves responding with a competitor to a call for tender (Pellegrin-Boucher et al., 2013). In the tourism industry, selling coopetition consists of developing common platform with competitors to sell complementary goods and services (Czakon and Czernek, 2016), defining a common offer, unifying quality standards, etc. (Kylänen and Mariani, 2012, 2014).

Selling coopetition is quite different from $R \& D$ coopetition (see Table 1). First, R\&D coopetition is a long-term, continuous process by nature (Gnyawali and Park, 2011). In contrast, selling coopetition is a discontinuous process that can be short term. Indeed, calls for tender are discontinuous, complex and unique by nature (Skaates and Tikkanen, 2003). Second, the drivers of $R \& D$ coopetition and selling coopetition differ. The aim of R\&D coopetition is to lower costs and increase technological knowledge (Gnyawali and Park, 2009). The goal of selling coopetition is to win a commercial market, a client or a call for tender. Third, measuring the value created in coopetitive $R \& D$ is difficult because the new knowledge created by coopetition is an intangible asset by nature. In contrast, the results of selling coopetition are easier to measure. Selling coopetition is a success if it results in increasing sales turnover, winning a call for tender or capturing market share.

As summarized in Table 1, R\&D coopetition and selling coopetition differ. Therefore, it seems necessary to study these two kinds of coopetition separately. In particular, it seems necessary to study how firms manage coopetitive tensions in selling activities.
Coopetition as a strategy under tensions

Coopetition is a particular relationship in which competition and cooperation are not exclusive but complementary (Bengtsson, and Kock, 2014; Czakon et al., 2014; Fernandez et al., 2014). Cooperation with a competitor does not entail a lower level of rivalry. Rather, this cooperation involves simultaneous collaboration and competition in a relationship that is finely balanced between the two opposite forces (Park et al., 2014). Therefore, coopetition creates tensions between and inside coopetitors (Tidström, 2013; Fernandez et al., 2014; Raza-Ullah et al., 2014; Lundgren-Henriksson and Kock, 2016; Stadtler and Van Wassenhove, 2016).

In coopetition, firms share their knowledge, resources and skills to jointly create higher value than they could create alone. The more they cooperate, the higher the resulting added value. However, each firm attempts to appropriate the joint value created through cooperation, which results in direct competition and conflict. The more they compete, the greater the resulting advantage for each individual firm. Therefore, coopetition is a strategy in which firms must simultaneously cooperate to create value and compete to appropriate and control the resulting value (Ritala and Hurmelinna-Laukkanen, 2009; Bouncken and Fredrich, 2012; Ritala and Sainio, 2014; Ritala et al., 2016).

By collaborating with a competitor, a firm might risk losing the secrets and control of its strategic organizational resources and competencies (Bouncken and Fredrich, 2012). When the gains obtained from the coopetitive relationship are asymmetric, they reinforce the competitive advantage of one firm but reduce the competitive power of the other (Dussauge et al., 2000).

Firms in coopetition are in a race to learn. By sharing knowledge, skills and resources, the focal organization risks reinforcing its coopetitor, which could harm the organization in the middle and long term. Depending upon its outcome, coopetition could be a win-win or win-lose strategy (Luo et al., 2007; Ritala and Hurmelinna-Laukkanen, 2009; Dagnino et al., 2012; Peng et al., 2012). Paradoxically, the more successful this strategy is, the more a company arms its competitor; the

Table 1 R\&D and selling coopetition

\begin{tabular}{llc}
\hline Characteristics & R\&D coopetition & Selling coopetition \\
\hline $\begin{array}{lll}\text { Cooperative activities } & \text { R\&D, production. } & \text { Sales and distribution } \\
\text { Type of shared resources } & \text { Technological (e.g., raw materials, know-how) } & \text { Commercial / market (e.g., customers, brands, distribution } \\
& & \text { channels, communication) } \\
\text { Time horizon } & \text { Long term } & \text { Long term or short term } \\
\text { Value creation } & \text { Continuous process } & \text { Continuous or discontinuous process } \\
\text { Value appropriation } & \text { Sharing R\&D costs } & \text { Winning a market, a client, a call for tender }\end{array}$ \\
\hline
\end{tabular}


competitor thus becomes even more dangerous (Hamel, 1991; Pellegrin-Boucher et al., 2013; Le Roy et al., 2016).

Consequently, coopetition is a strategy involving multiple tensions (Fernandez and Chiambaretto, 2016; Le Roy and Czakon, 2016). These tensions are initially felt at the top management level. Relevant questions include which governance of the common project must be implemented to avoid risks and benefit from coopetition (Bouncken et al., 2016; Le Roy and Fernandez, 2015), who is in charge of commercialization of the common project (Fernandez et al., 2014), among others. These tensions are then felt at the organizational level, where operations are organized between the competitors (Le Roy and Czakon, 2016). Tensions are high at this organizational level because of differences between industrial processes, between protecting and sharing information, and so forth (Fernandez et al., 2014; Fernandez and Chiambaretto, 2016). Finally, tensions are high at the individual level. People feel cognitive and affective tension because of individuals' reluctance regarding the coopetitive work and because of the difficulty of integrating coopetitive paradoxes (Gnyawali and Park, 2011; Fernandez et al., 2014; RazaUllah et al., 2014; Lundgren-Henriksson' and Kock, 2016; Stadtler and Van Wassenhove, 2016).

Coopetitive tensions are generated by the coopetitive situation, and they cannot be reduced to zero. Because firms cannot avoid tensions, they must manage them. Thus, the solution is not to avoid conflicts and eliminate tensions but rather to manage these tensions constructively.

\section{Management of coopetitive tensions}

The coopetition management literature is divided into two main schools of thought depending on the main managerial principle to be applied to manage coopetitive tensions: separation or integration (Le Roy and Czakon, 2016).

Separation principle. According to the first school of thought, organizational separation between competition and cooperation helps employees to avoid the coopetition paradox. They can focus on managing either collaborative or competitive actions (Dowling et al., 1996; Bengtsson and Kock, 2000; Oliver, 2004; Herzog, 2010). Thus, for Bengtsson and Kock (2000: 410), 'the two different types of interaction are not divided between counterparts, but between activities, as it is impossible to compete and cooperate in the same activity'.

Such separation can be realized in various ways. Previous studies have proposed two different solutions to achieve separation. The first involves specifying a functional unit in which collaboration occurs and another unit that maintain a competitive relationship. The most current situation entails collaborating in $R \& D$, competing for sales, and creating a dedicated service to manage the alliance. Alliance managers are professionals who are devoted to managing partnerships and alliances, including alliances with competitors (Bouncken and Fredrich, 2012). The second solution involves developing collaboration with a competitor for a specific product market while competing in other product markets.

Integration principle. In this second school of thought, the separation principle is not considered an effective solution. Rather, it is considered a source of organizational tensions (Clarke-Hill et al., 2003; Oshri and Weber, 2006; Chen, 2008; Gnyawali et al., 2008). If an employee cannot understand the role of his or her colleagues in other functions, this can create internal conflict and suspicion. To avoid this problem, all personnel must be familiar with the global strategy of their firm and develop a coopetitive mind-set.

Another managerial principle that should be applied is integration. In adopting this principle, organizations do not attempt to negate, hide or suppress the existence of conflicting forces. They aim to create a dynamic equilibrium by implementing a series of specific managerial procedures (Clarke-Hill et al., 2003; Oshri and Weber, 2006; Chen, 2008; Gnyawali et al., 2008). Individuals with an integrative mind-set are better equipped to manage competition and collaboration simultaneously (Oshri and Weber, 2006).

The principle of integration is close to the principle of acceptance (Smith and Lewis, 2011). To avoid internal conflict and tensions arising from the implementation of the separation principle, people in a coopetitive context must develop the capability to integrate coopetition in their mind and address the paradoxical nature of coopetition.

Towards other principles. The debate on the efficiency of coopetition management principles remains open. The separation principle has limitations. Efficiently managing coopetition solely by using this principle seems difficult. However, the integration principle is not without limitations. According to Smith and Lewis (2011), individuals can accept paradoxical tensions only if they develop high cognitive and behavioral complexity and high emotional equanimity. Therefore, integrating the coopetitive paradox may be difficult for some organizational members. Doing so is an affective, cognitive and behavioral challenge (LundgrenHenriksson' and Kock, 2016), particularly for employees of Western companies (Dagnino et al., 2012). Moreover, the challenge of integration is never completely resolved. Coopetition creates continuous tensions, and these 
tensions can become unbalanced and create vicious cycles that force managers to remain vigilant because people often tend to revert to their past attitudes.

Following this idea, some authors consider the separation and integration principles to be complementary rather than opposites (Fernandez et al., 2014; Fernandez and Chiambaretto, 2016; Seran et al., 2016). Separating competition and cooperation permits the management of inter-organizational tensions but creates new internal tensions. If individuals can integrate coopetitive logic, these internal tensions can be managed. Therefore, separation and integration enrich each other. Effective management of coopetition thus simultaneously combines the separation and integration principles.

Le Roy and Fernandez (2015) further argue that combining the integration and separation principles is not sufficient to successfully manage coopetition in an $R \& D$ project. They show that at the project level, firms implement a coopetitive project team based on an additional principle - the co-management principle. Such co-management permits the development of innovative projects with a high level of knowledge sharing. With co-management, firms can control knowledge exchanges to monitor both each other and the day-to-day advancement of the project.

\section{Research questions}

Debates dedicated to the relevance of coopetition management principles occur mainly within research focused on R\&D coopetition. The relevance and limitations of coopetition management principles with respect to selling coopetition have not been investigated. Many coopetitive agreements are nevertheless established for selling activities, which are quite different from $R \& D$ activities (see Table 1). Therefore, further research is needed to determine the relevance of coopetition management principles to selling coopetition. Accordingly, this research aims to answer the following questions: What management principles are relevant to managing selling coopetition? Is the separation principle relevant to managing selling coopetition? Is the integration principle relevant to managing selling coopetition? Which additional principles should firms use to manage selling coopetition? These questions are summarized in our research framework (see Figure 1).

\section{Method}

\section{An in-depth case study approach}

To answer our research questions, we chose to apply a qualitative in-depth case study method. Our goal is to gain a deeper understanding of 'how' selling coopetition tensions can be managed (Harryson et al., 2008; Yin, 2013). Our choice is justified by the complexity of our research subjects and by the lack of an established theory concerning the management of selling coopetition. Eisenhardt (1989) recommends using this method when research addresses an unexplored phenomenon. This is necessary here because no empirical study has examined the management of selling coopetition. Furthermore, in the coopetition context, Bengtsson et al. (2010) underscore their interest in case studies to better understand the complexity and implications of this type of relationship. Gnyawali and Park (2011) and Fernandez et al. (2014) also highlight the role of the case study approach in examining the management of the paradoxical situation created by coopetition.

We choose to develop a case study in the ICT sector. Alliances and partnerships between competitors are very frequent and particularly intense in this sector (Shapiro and Varian, 1999; Fjeldstad et al., 2004; PellegrinBoucher et al., 2013). For instance, SAP, the global leader of business software, works with an international network of more than 13,000 partners (SAP, 2015). In the last 20 years, Internet interconnectivity has lowered market entry barriers, creating global hyper-competition (Shapiro and Varian, 1999). However, the existence of standards, the interoperability of software and equipment, the convergence of technologies, and the continuous level of innovation have imposed greater technological cooperation and increased the pooling of resources among companies (Fjeldstad et al., 2004; Taylor, 2005). The advantage of market pioneers (Katz and Shapiro, 1994) demonstrates the importance of inter-firm associations. Companies prefer to win as a group rather than lose alone. A technology with quick market penetration has a better likelihood of being adopted as a technological standard.

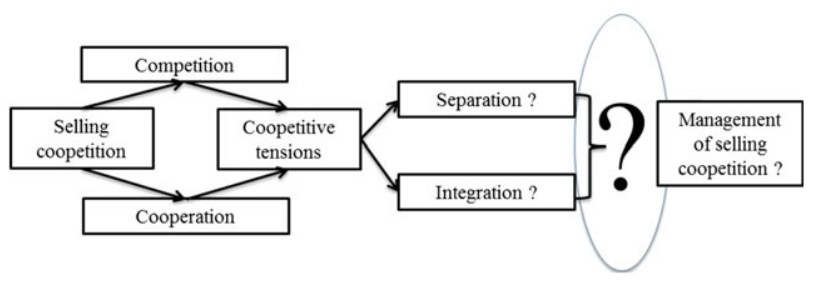

Figure 1 Theoretical framework

Source: adapted from Fernandez et al. (2014). [Colour figure can be viewed at wileyonlinelibrary.com] 
Market pioneers can then take advantage of the 'lock in' effect (Arthur 1989, 1994) and the high costs of changing technological systems (Ritala and HurmelinnaLaukkanen, 2009).

In this context, rival firms are forced to collaborate in order to ensure compatible standards, increase their networks, gain new markets and enhance customer value (Oracle Financial Services, 2015; SAP, 2015). The competitive behavior of ICT companies has evolved towards increased coopetition (Contractor and Lorange, 2002; Fjeldstad et al., 2004; Hallikas et al., 2006). The real question for many ICT firms is not whether to adopt a coopetitive approach but rather how to manage coopetition.

Our research focuses on the ERP and business applications sector. We studied the management of selling coopetition among three main competitors in the ERP industry: SAP, Oracle and IBM (see Table 2). We chose ERP because this industry offers numerous examples of coopetitive selling agreements (Troesch and Schikora, 2010).

The coopetitive selling agreements in ERP are driven by the industry value chain (Pellegrin-Boucher et al., 2013). ERP applications are software programmes that facilitate the integration and management of organizational processes through the use of a unique platform. These information systems are based on client-server technology that integrates a series of modular applications that share and use a centralized database. Thus, firms that wish to use ERP must adopt a central operation system, install a database and introduce an application server. The final modular solution is usually implemented by specialized service organizations, increasingly through cloud systems. The value-added chain of the ERP sector thus comprises four main elements: (1) developers of ERP and application systems, such as SAP and Oracle; (2) developers of database systems, such as Oracle, SAP and IBM; (3) suppliers of application servers, such as IBM, Oracle and SAP; and (4) service providers, such as IBM (see Table 2). Throughout this value chain, firms are simultaneously partners and competitors.

\section{SAP: The leader in ERP and business solutions}

SAP is a German company that conceives and sells software applications, particularly ERP systems. The company is the largest software designer in Europe and the fourth largest in the world (PwC, 2014). In addition, SAP is the world leader in the ERP sector, the world's largest business software company and the third largest independent software provider by revenue. SAP's systems work on IBM and Oracle equipment. They can be set up by the services departments of these rival companies but also by the integration division of SAP or by consulting firms or software engineering companies (e.g., Deloitte, Accenture, and Cap Gemini). Partnerships and selling alliances are central to the functioning of this business ecosystem. At the same time, with the development of SAP's integrated technology platform, the competition with IBM and Oracle became increasingly direct and intense.

Oracle: the leader in database systems and second in the ERP industry

Oracle Corporation is a US-based computer technology corporation. The company specializes in developing and marketing computer hardware and enterprise software products, particularly database management systems. Oracle is the second largest software producer by revenue, after Microsoft. The company also builds tools for database development and systems of middle-tier software, ERP, customer relationship management (CRM), and supply chain management (SCM) applications. After SAP, Oracle is the second most important firm in the ERP industry. In addition, Oracle

Table 2 Dominant actors in the ERP and business applications sector

\begin{tabular}{|c|c|c|c|c|}
\hline & Developers of ERP systems & Developers of database systems & Suppliers of application servers & Services/cloud \\
\hline Definition & $\begin{array}{l}\text { ERP is a software system } \\
\text { that integrates and } \\
\text { manages various } \\
\text { functions of an } \\
\text { organization }\end{array}$ & $\begin{array}{l}\text { A database software is a } \\
\text { system for organizing } \\
\text { data which allows the } \\
\text { rapid localization and } \\
\text { updating of data items }\end{array}$ & $\begin{array}{l}\text { An application server is a server } \\
\text { that hosts the software } \\
\text { applications of an organisation. } \\
\text { This server is a central software } \\
\text { program within a multi-layer } \\
\text { software architecture }\end{array}$ & $\begin{array}{l}\text { They represent service and/or } \\
\text { consulting firms that are } \\
\text { specialised, among others, } \\
\text { in implementing ERP } \\
\text { systems in client } \\
\text { organisations and in } \\
\text { providing cloud systems }\end{array}$ \\
\hline Global leader & $\mathrm{SAP}$, in the last 20 years & $\begin{array}{l}\text { Oracle, in the last } \\
20 \text { years }\end{array}$ & IBM & IBM \\
\hline Dominant actors & SAP, Oracle, Microsoft & $\begin{array}{l}\text { Oracle, IBM, SAP, } \\
\text { Microsoft }\end{array}$ & IBM, Oracle, SAP & $\begin{array}{l}\text { IBM, HP, SAP, Oracle, Google, } \\
\text { Microsoft, Amazon, Dell, } \\
\text { Accenture, Capgemini, CSC, } \\
\text { Ernst \& Young, Deloitte, Tata }\end{array}$ \\
\hline
\end{tabular}

Source: adapted from Pellegrin-Boucher et al. (2013). 
is the global leader in databases, but its systems are very dependent on SAP products that run on Oracle software and on IBM infrastructures. Consequently, IBM and SAP represent key partners of Oracle but also direct competitors because all three companies have important hardware and software divisions.

\section{IBM: the leader in IT services}

IBM is an American technology and consulting corporation. IBM manufactures and markets computer hardware and software and offers infrastructure, hosting and consulting services in areas ranging from mainframe computers to nanotechnology. Its services subsidiary is a global leader, and IBM remains the largest global supplier of infrastructure software (PwC, 2014). IBM develops Bto-B software applications such as CRM and SCM, which are direct competitors of ERP and solutions developed by SAP and Oracle. IBM is a direct competitor of SAP and Oracle with respect to ERP business as well as services, applications servers, and so forth. Despite this competitive situation, since the 1990s, IBM, SAP and Oracle have developed a series of technology and selling partnerships (see Table 3).

\section{Data collection and research process}

Considering the complexity and specificity of coopetitive strategies, a qualitative methodology based on a content analysis of the primary data (interviews) and secondary data (i.e., press articles, internal documents, and guidelines) was used.

The three case studies were conducted by using the same three phases: secondary data collection, primary data collection and secondary and primary data triangulation.
The empirical study lasted three years. First, the secondary data collection phase was conducted by using online professional forums and by collecting sector and firm information. This phase included a historical analysis of the creation and development of the industry from 1990 to 2015, with a special interest in the period from 2005 to 2015. Indeed, this represents a period of increasing coopetition between the studied firms, when SAP entered into the server market and became an even more aggressive competitor of IBM. Lasting six months, this exploratory phase improved our definition of the research question and helped us to create an interview guide.

Second, the interview phase provided insights into the respondents' personal perceptions and attitudes concerning the coopetitive selling situation and associated management procedures. During this phase, which lasted two years, we conducted 42 semi-structured interviews with alliance managers and their counterparts in business partners (see Table 4). The respondents have different function titles, such as alliance managers, project heads, and partner managers, depending on their firms. In their work, however, they are always involved in selling coopetitive agreements.

The respondents were contacted based on previous professional links. One of the authors was a consultant in the ERP industry and personally knew some of the respondents. With the snowball method, personal contacts were provided to the authors by the first respondents. All interview requests were accepted, and each interview lasted from one to three hours.

After establishing the criteria for the qualitative analysis (Eisenhardt, 1989; Yin, 2013), we began our research by interviewing managers from the three main companies studied (SAP, Oracle and IBM). We then interviewed

Table 3 The three case studies

\begin{tabular}{|c|c|c|c|}
\hline Firms & $I B M$ & Oracle & $S A P$ \\
\hline Position on markets & World leader in IT services & $\begin{array}{l}\text { World leader in database systems. } \\
\mathrm{N}^{\circ} 2 \text { in ERP and business } \\
\text { solutions systems }\end{array}$ & $\begin{array}{l}\text { World leader in ERP and business } \\
\text { solutions systems }\end{array}$ \\
\hline Revenue in 2015 & 81,7 Mds USD & 38,27 Mds USD & 17,31 Mds USD \\
\hline Net Result in 2015 & 13,2 Mds USD & 9,95 Mds USD & 3,32 Mds USD \\
\hline Employees in 2015 & 377757 & 135078 & 74497 \\
\hline Activities & $\begin{array}{l}\text { Software (business solutions), } \\
\text { hardware (mainframes, } \\
\text { databases, servers), } \\
\text { consulting services } \\
\text { Services }=50 \% \text { of turn over }\end{array}$ & $\begin{array}{l}\text { Software (business solutions), } \\
\text { services and hardware } \\
\text { (Sun Microsystems) }\end{array}$ & $\begin{array}{l}\text { Software, services, technology } \\
\text { computing platforms }\end{array}$ \\
\hline $\begin{array}{l}\text { Activities within ERP } \\
\text { and business software } \\
\text { industry }\end{array}$ & $\begin{array}{l}\text { Sells and implements SAP } \\
\text { products with IBM products } \\
\text { (servers, computing platforms, etc.) }\end{array}$ & $\begin{array}{l}\text { Sells ERP, CRM and SCM } \\
\text { software applications and } \\
\text { databases for ERP and SAP } \\
\text { systems }\end{array}$ & $\begin{array}{l}\text { Sells ERP, CRM and SCM } \\
\text { software applications with } \\
\text { computing platforms }\end{array}$ \\
\hline Coopetition & \multirow{2}{*}{\multicolumn{3}{|c|}{$\begin{array}{l}\text { Their systems are interdependent and complementary on some markets/activities and competing at the same time } \\
\text { They cooperate since the 90's because SAP systems work on IBM and Oracle infrastructures }\end{array}$}} \\
\hline Marketing and selling alliances & & & \\
\hline
\end{tabular}

Source: Annual Reports. 
Table 4 List of interviews

\begin{tabular}{|c|c|c|c|}
\hline \multicolumn{2}{|l|}{ Large firms } & \multicolumn{2}{|l|}{ SMEs } \\
\hline Company & Profile & Company & Profile \\
\hline Oracle, SAP, IBM & 16 Alliance managers and directors & Company A, Company B, Company C, & 1 President \\
\hline Microsoft, Accenture, Bearing & 3 Sales people & Company D, Company E & 3 CEOs \\
\hline Point, Capgemini, Deloitte & 4 Heads of project & & $\begin{array}{l}3 \text { Heads of department } \\
2 \text { Sales people }\end{array}$ \\
\hline Respondents & 23 & Respondents & 9 \\
\hline Interviews & 33 & Interviews & 9 \\
\hline
\end{tabular}

people from their corporate partners (SMEs and multinationals) to compare their perceptions. The target respondents were alliance managers, as designated by their functional role or hierarchical position, with significant experience in alliance and coopetition management (Taylor, 2005).

The second round of interviews was conducted with managers at different levels (e.g., project heads and CEOs) to gain a better understanding of the direct and indirect coopetitive tensions affecting the coopetitors. To ensure that the investigated companies were competitors and that they had established selling coopetitive links, we retained only firms that sold products or services on the same market and to the same clients. We directly checked these competing relationships with the interviewees. We also verified the nature of the relationships with the interviewees. In all cases, we analysed only dyadic alliances between competitors that included one of the studied firms, namely, SAP, IBM, or Oracle. Ultimately, face-to-face in-depth interviews provided access to the personal opinions and experience of 32 people involved in the management of selling coopetition. These various sources allowed a more complete analysis of the managerial mechanisms applied in these coopetitive relationships (O'Brien and Linehan, 2014).

Finally, in the triangulation phase, we combined the data obtained from the first two steps and added a new range of secondary data. We used guidelines on coopetition, other internal strategic documents that we had collected during the interviews, recent articles from management journals, company annual reports, market analyses and press releases. The data collected from the interviews were evaluated, enriched and verified with these secondary data. The goal was to ensure a high level of rigour in terms of internal and construct validity (Gibbert et al., 2008). We also checked the validity of these insights with expert reports in the ICT sector. The availability of various sources allowed us to conduct a first round of triangulation to examine the data from multiple vantage points (Glaser and Strauss, 1967; Capasso and Dagnino, 2014). Second, we triangulated the interview transcripts and internal reports to achieve cross- verification from multiple sources and to improve the study's validity. This triangulation facilitated an iterative process for analytic refinements.

\section{Codification and analysis}

According to Miles and Huberman (1994), qualitative microanalysis involves a detailed investigation of every data category to define the basic concepts, their properties and dimensions and then to identify relationships between various concepts. In this study, data coding and analysis concerning coopetitive and dyadic selling links were manually conducted (see Appendix).

Using the frameworks developed by Bengtsson and Kock (1999, 2000), we applied the first level of coding to define the nature and modes of coopetition. We identified the co-existence of collaboration and competition as well as the nature, type, mechanisms, tensions, effects, and organizational formalization of coopetition. We also identified the procedures and process used to manage coopetition.

Using the Fernandez et al. (2014) framework, we then divided the content of various discourses into units of analysis, which were again classified into several categories. The retained units of analysis were parts of sentences, full sentences or groups of sentences addressing the same themes: (1) integration of coopetition; (2) separation of cooperation and competition; (3) mechanisms and procedures; and (4) tensions.

We applied the second level of coding - open and axial - to enrich the results and, consequently, the existing theory. Open coding is used to discover, define and develop new categories within the collected data (Strauss and Corbin, 1998). Each identified concept has specific characteristics and dimensions that facilitate its abstract definition and codification. When this method is applied, data are classified into several distinct categories depending upon their similarities and differences. The newly identified categories can then be used to propose enriched theoretical models or concepts. For example, such topics may include: (1) selling coopetition; (2) exclusivity deals vs. collective deals; (3) calls for tender; 
(4) formal and informal management; (5) limitations of separation and integration; (6) lack of trust; (7) advantages and limitations of the role of the alliance managers; (8) internal and external tensions; (9) arbitration; and (10) the antagonistic interests and roles of alliance managers and sales people.

\section{Results}

The analysis of the interviews and documents provided by the respondents indicates that coopetition has become a standard for multinational companies in the ICT sector. Aware of this necessity, these firms develop and implement coopetition strategies using a specific organizational design and managerial procedures and process.

\section{An organizational design for selling coopetition}

Because of increased customer demands for information system integration and flexibility, coopetition strategies are very common in the ICT sector. Some firms have deliberately implemented this type of strategy to develop and diversify their markets. The case of IBM is exemplary. At the beginning of the 1990s, the new CEO, Lou Gerstner, implemented a general policy of development based on coopetitive relationships. IBM decided to sell several technologies and innovations to its competitors in order to transform them into customers and/or partners. This strategic move was initially negatively perceived as 'arming the enemy'. It represents an important strategic revolution in relation to not only IBM's previous strategies but also the strategies adopted by other companies in this sector. Despite facing criticism, the CEO of IBM was convinced that providing competitors with IBM technology would create additional value for customers. Today, the generalization of these practices has forced firms to manage coopetitive relationships even when they aim to limit or eliminate potential dysfunctions (quotation 1; see Appendix 4 for list of quotations).
Since the beginning of the 1980s, alliances between competitors in selling have grown each year and have become standard behavior in the ERP industry. When SAP decides to answer a call for tender, SAP must choose between individual and coopetitive selling. In individual or exclusive deals, SAP proposes an entire SAP solution to the client (e.g., applications, database, and services). In a coopetitive offer, one of two options is used (see Figure 2). In the first option, which is the most common, cooperation is vertical. SAP proposes a common solution with a competitor, such as Oracle, concerning complementary products. Thus, one strategic business unit (SBU) of SAP (e.g., the SBU for ERP) establishes a selling agreement with an SBU of Oracle (e.g., the SBU for databases). In the second option, cooperation is horizontal. The offer concerns products from the same type of SBU. For example, Oracle and SAP ally to propose a common ERP system.

To manage these two types of selling coopetition, large ICT firms such as IBM, Oracle and SAP have formalized an organizational design (see Figure 3 ) based on a divisional structure. The first function is cooperative and represented by alliance managers. The second function is competitive and represented by the sales force (quotations 2 and 3). As with mythical Janus, the companies present a double face, simultaneously cooperative and competitive, with employees invested in either a cooperative-dominant or competitive-dominant mission.

In this organizational design, top managers develop and implement various procedures to favour competition and cooperation between firms. Within IBM, Oracle and SAP, these roles are clearly defined and formalized using professional objectives related to job descriptions. For example, alliance managers are generally paid according to the turnover (sales) realized in association with partner organizations. In contrast, sales people are paid in direct relation to the commercialization of a company's own products.

This dual structure has the advantage of facilitating internal relationships because the divisions of the same firm are separated to avoid or reduce conflicts of interests.



Figure 2 Coopetitive selling in the ERP industry 


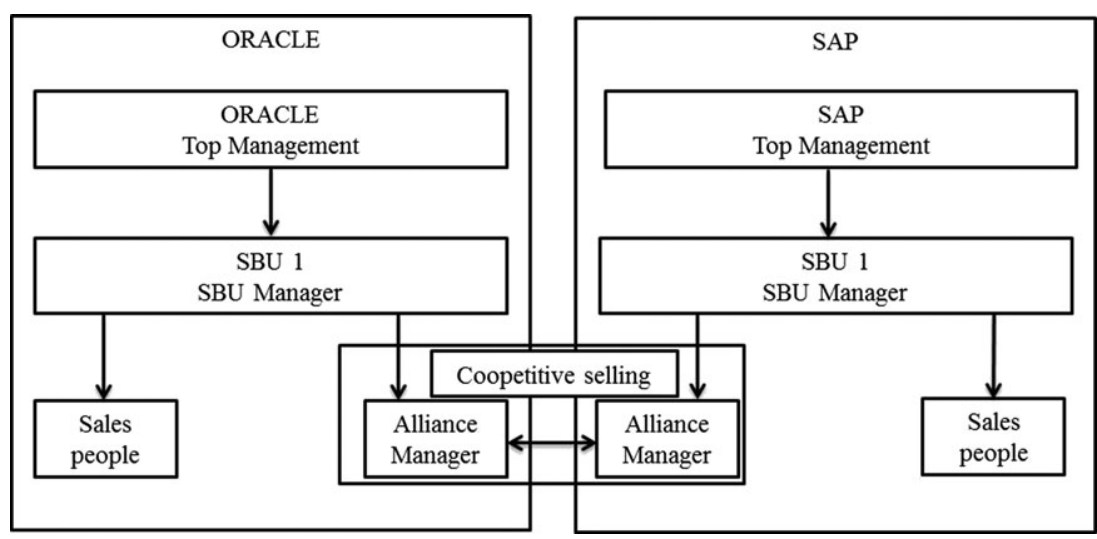

Figure 3 Organizational design for coopetitive selling

The structure also facilitates external relationships because only certain individuals, namely, alliance managers, cooperate with other firms. In these conditions, partners are satisfied to have in front of them people who wish to develop inter-firm collaboration.

Most of the interviewed alliance managers give priority to cooperation (quotation 4). They predominantly use words related to cooperation; the representatives of other firms, even competitors, are considered partners (quotations 4-7). Alliance managers often consider themselves to have a collaborative mission that takes precedence over any other type of activity, particularly competitive activities.

\section{Role of alliance managers}

The role of alliance managers corresponds to a real need for complex partnerships involving competing firms. In line with their cooperative mission, alliance managers connect and coordinate activities and interests between rival firms. By promoting the interests of their company, alliance managers influence the partner company (quotation 8). Ultimately, this capacity to influence is based on trust, which is difficult to develop between competing firms (quotation 9). To eliminate this distance, firms might jointly organize various social actions, providing opportunities for informal meetings and discussions. These socialization initiatives facilitate the transition towards more personalized and relational management, which strengthens a firm's ability to influence its partner organization.

An additional objective of these relationships is for partners to exchange information about new market opportunities (quotation 10). The strategic goal in many situations is to ensure a good relationship with the partner (quotation 11). The interview data indicate that trust can indeed develop even between alliance managers of directly competing firms (quotation 12). Nevertheless, activities of alliance managers are often obstructed by various difficulties such as role ambiguity within the firm, misunderstandings with other internal managers or employees, and a lack of credibility in relation to partner firms.

\section{A permeable organizational structure with internal and external tensions}

The divisional structure permits a primary definition of employee roles. However, most employees are still confronted with the ambiguity and paradox of coopetition. Even when firms cooperate to develop complementary products, promoting a competitor's product or service is difficult when the same type of product or service exists within the focal company (quotation 13). Within their own firms, alliance managers can be perceived as traitors who help the enemy. This perception weakens the internal legitimacy of alliance managers. It can further block some of their propositions and actions through a lack of resources or budget cuts, eventually resulting in alliance failure. From the partner's perspective, the situation is also complex and occasionally very strained. Indeed, several alliance managers in this study openly criticized the uncooperative behavior of their counterparts from partner companies.

The divisional model cannot be applied in all situations, as many exceptions at the organization, market or valuechain level can invalidate a strict division between cooperation and competition. For example, commercial agents, who are traditionally involved in competitive actions, might be obliged to initiate collaborative projects with competing firms. This situation occurs when the client requires solutions integrating the products or services of several competing firms. Moreover, many alliance managers are confronted with competitive situations when partnering relationships are unsuccessful and when a partner becomes too aggressive in the market. An alliance can be so competitive that it is almost impossible for alliance managers to do their job. In such 
a case, the alliance might be terminated after several months, as in the case of the global selling alliance between SAP and Oracle in 2007.

In conclusion, the implementation of a divisional structure and the action of alliance managers to promote cooperation are insufficient to manage coopetitive tensions. Employees within the divisional structure feel both internal and external tensions. Therefore, firms in the ICT sector have formalized organizational rules to permit a better understanding of the role of each employee.

\section{Organizational rules to integrate coopetition}

Firms have implemented organizational rules to facilitate individuals' understanding of coopetition strategies. For instance, IBM issued explicit internal guidelines concerning the importance of combining collaboration and competition. These directives provide concrete answers to complex coopetitive situations (see Appendix 1). They clarify the stakes and purpose of coopetition strategies. These guidelines facilitate the daily work of managers, helping them to integrate opposite objectives, improve their efficiency, and enhance interorganizational performance (quotation 14). When these principles and guidelines are well integrated into everyday practice, managers apply them implicitly (quotation 15).

The guidelines explain and formalize the practical procedures of integrating coopetition at the organizational and individual levels. Individuals must accept the paradox without sacrificing one principle for the benefit of the other. The company hence preserves both paradoxical forces at the organization level and establishes precise rules that limit managerial indecision at the individual level.

For example, a note sent by the IBM top management team concerning the relationship between IBM and SAP encouraged project managers to change their mind-set. The IBM note explained that this relationship is not an extreme situation but rather an ordinary reality that does not question or threaten the competitiveness of the company. For IBM, 'within our market, which is more and more open and competitive, the customers are confronted with a very wide choice of IT solutions. Our company is actively present in almost all areas of activity; nevertheless, the customer may prefer a solution which includes components that do not come from our labs. This means that we sometimes need to cooperate with competitors without questioning our capacity to remain aggressive and competitive in the market'.

The above statement leads to two basic principles that should always be considered simultaneously in a balanced manner by IBM project managers. The first principle concerns 'customers' expectations', in which 'the interest of companies is to maximize customer value, since customers are the final market arbiters'. Therefore, 'companies initiate partnerships and strategic alliances to offer a more commercially attractive and diversified range of solutions, which are ultimately profitable for all involved actors, even if they are competitors'. The second basic principle is 'shareholders' expectations', in which the 'company's profit is maximized by selling more products and services, which include a larger proportion of their own input, and valorize their own brand name'.

In conclusion, as the implementation of a divisional structure is insufficient to manage coopetitive tensions, companies implement organizational rules to instil a better understanding of coopetition in their employees. Nonetheless, these organizational rules are still insufficient to manage coopetitive tensions.

\section{Divergent and irreconcilable interests lead to arbitration}

The results show that despite organizational design and internal organizational rules, sales people and alliance managers often experience conflicts of interest (quotations 16 and 17). These conflicts arise from their incentives. Alliance managers have an incentive to pool their resources with partners, even competing firms. Conversely, sales people have an incentive to sell their own firm's solutions as much as possible (see Appendix 2). These opposing interests are impossible to reconcile inside the organization. Thus, the organizational design implemented to manage the coopetitive paradox has important limitations.

To resolve the persistent conflict of interest between sales people and alliance managers, top management teams use arbitration (quotations 18-20). Arbitration is implemented at a business unit level in large firms or at the top level in smaller firms. Arbitration is used when sales people and alliance managers want to answer the same call for tender. To avoid proposing two competing answers within the same firm, the top manager decides who should go to the market. Therefore, through arbitration, the final solution between the individual solution pushed by sales people and the coopetitive solution pushed by alliance managers is determined.

Internal arbitration is a hierarchical process that permits organizations to solve conflicts between sales people and alliance managers. Arbitration is used a posteriori when there is a situation of conflict. However, the resolution is temporary, and a new problem can arise soon because conflicts of interest between sales people and alliance managers are structural and consubstantial to selling coopetition.

\section{Discussion}

This study attempts to identify the main principles and procedures required to manage selling coopetition 
successfully. The results suggest that effective management of selling coopetition depends upon a dynamic combination of separation, integration and arbitration.

\section{Separation principle in selling coopetition management}

The present findings regarding the relevance of the separation principle are consistent with some findings of past studies (Dowling et al., 1996; Bengtsson and Kock, 2000; Oliver, 2004; Herzog, 2010). In selling coopetition, activities are clearly separated at the individual level. A person is concerned with only one dimension of the coopetitive paradox. This role attribution is in line with a company's positioning and strategy, and the role of each concerned person should be complementary, not conflicting. The key factor is the organizational design. The difficulty lies in defining a relevant structure that separates competition and cooperation. Once this separation is achieved, each individual knows what he or she must do. Therefore, individual uncertainty is very low, with high personnel efficiency.

The results advance our knowledge about the advantages of the separation principle for selling coopetition. Separation simplifies design and implementation and eliminates conflicts of interest from the start. By separating competitive and cooperative activities, a firm can eliminate the need for specific control mechanisms dedicated to identifying and solving emerging conflicts. Moreover, task specialization can occur among individuals. Employees do not need to maintain a permanent balance between competition and collaboration.

However, the results also advance our knowledge about the disadvantages of the separation principle for selling coopetition. Adopting the separation principle alone is not sufficient to efficiently manage selling coopetition. First, separation cannot be complete. Indeed, as the results show, sales people and alliance managers sometimes target the same market. Second, during a coopetitive project, the top management team should continually monitor and balance the evolution of the two conflicting forces in relation to the operational and strategic priorities of the company. However, these actions might not be easily accepted and understood by individuals specializing in a specific area of coopetition. In this situation, each person tends to prioritize activities related his or her specific mission. Thus, the seemingly paradoxical decisions of the top management team may be questioned by operational managers.

\section{Integration principle in selling coopetition management}

As noted by some scholars, individual integration regarding coopetition is needed (Clarke-Hill et al., 2003; Oshri and Weber, 2006; Chen, 2008; Gnyawali and Park, 2011). The application of the integration principle results in less separation between competitive and cooperative activities. Individuals involved in coopetitive projects are oriented towards specific objectives, but they are free to choose when and how to use cooperation or competition in their relationship with organizational partners.

In selling coopetition, alliance managers have an essential role in integrating collaboration and competition at both the organizational and individual levels. Their activity is structured and supported by formal guidelines released by the top management team. In this configuration, both the organization and individuals are more responsive and adaptable to specific coopetitive situations. The daily tensions created by conflicting forces are usually managed by employees without top management involvement. This approach is particularly suitable for SMEs, as it increases organizational flexibility and responsiveness and allows individuals to integrate the coopetitive paradox into their daily actions.

The disadvantages associated with integration are related to possible strategic deviations and inefficiencies caused by individuals' inability to dynamically and simultaneously address two coopetitive forces. In this sense, people may be unable to apply a logic that does not serve their interests, as alliance managers and sales people have divergent commercial interests. The managerial process might not be capable of solving existing ambiguities, and one coopetitive dimension may be sacrificed to resolve these contradictions. Individuals' behavior is also more unpredictable because various employees might choose a different solution for the same problem. Therefore, it is possible to conclude that the integration principle is not fully efficient in managing selling coopetition. Even if it is driven by organizational procedures, integration cannot be sufficient to solve the conflict between sales people and alliance managers.

It is also possible to conclude that for coopetitive selling, combining separation and integration is not sufficient. This combination is considered by some scholars to be an efficient solution to manage the coopetitive paradox (Fernandez et al., 2014; Fernandez and Chiambaretto, 2016; Seran et al., 2016). Implemented together, the integration and separation principles would counterbalance their negative effects and permit the creation of a virtuous coopetitive circle. Our results do not confirm this perspective. Separation and integration together are not sufficient to manage selling coopetition successfully.

\section{Arbitration principle in selling coopetition management}

The results reveal permanent conflicts of interest between sales people and alliance managers inside the firm. The first driver of these conflicts is rational and is directly 
linked to the conflicting incentives of sales people and alliance managers. Sales people and alliance managers are in an internal competition to win calls for tenders. The outcome of this competition directly impacts their bonus at the end of the month. This internal win-lose game arises from the implementation of the separation principle.

The second driver of conflicts is more affective. Every day, sales people fight against the firm's competitors to win calls for tenders. The level of aggressiveness on the market is very high, and competitors are 'mortal enemies' for sales people. Therefore, sales people find it very difficult to accept that their firm works with a competitor that is their aggressive enemy on a daily basis. Furthermore, it is difficult to accept that an employee of their own firm, that is, the alliance manager, works with this "mortal enemy". Sales people are deeply attached to the products of their firm, and they feel that they alone should win calls for tender. This affective disturbance is common in coopetitive situations (Lundgren-Henriksson' and Kock, 2016) but is even stronger in selling coopetition. High levels of inter-individual tensions can turn into personal hate.

In this situation of rational and affective conflict, it is impossible for alliance managers and sales people to find a solution by negotiating. Individuals should not give up a call for tender if they think that they can win. If they cannot find any suitable arrangement, top management should arrange arbitration. Without this arbitration, tensions would be too high inside the firm, and the image presented to the customer would be very damaging for the firm.

Arbitration is an internal hierarchical choice conducted by top management between coopetitive selling and purely internal selling. Arbitration depends on strategic factors such as the commercial context, the history of the client relationship, client needs, and the technology available. The basic question is to determine whether it is possible to win the call for tender alone. The final choice is a balance between the customer expectations, the internal solutions available and the skills of the partner. This decision must be made by top management because sales people and alliance managers are too involved in their own personal situations. Arbitration permits conflicts to be resolved, but such resolution is temporary by nature.
New arbitration will be necessary for future conflicts. Thus, arbitration is not a one-shot decision but a permanent managerial process for firms involved in coopetitive selling.

\section{Global selling management combining separation, integration and arbitration}

Our findings highlight the debate on relevant coopetition management principles for selling coopetition. ICT firms engaged in a selling coopetition strategy tend to implement organizational design based on the separation of competition and cooperation. This design solves the problem in the short term but creates new long-term tensions. To manage these tensions, firms urge their managers to integrate the coopetitive paradox, but this integration is not sufficient. Conflicts of interest are created and recreated by the coopetitive situation. Therefore, it is necessary to implement a third principle, namely, the arbitration principle.

This finding is in line with Le Roy and Fernandez's (2015) idea that coopetition requires additional principles to be managed efficiently. Studying an R\&D coopetition context, Le Roy and Fernandez (2015) argue that in addition to the separation and integration principles, firms must adopt a co-management principle. We do not find this co-management principle in selling coopetition. The additional principle needed is hierarchic arbitration. Efficient management of selling coopetitive tensions is permitted by a combination of three principles: separation, integration and arbitration (see Figure 4). These three principles have their own managerial procedures, advantages and limitations (see Table 5). The advantages of each compensate for the limitations of the others; implemented separately, they cannot be successful.

This research shows that selling coopetition is generally quite different from $R \& D$ coopetition. The key point is the role of the client. In R\&D coopetition, collaborating with a competitor is a long-term strategy with high involvement. In selling coopetition, the decision is short term and can be made at the last moment by arbitration from top management. Top management must quickly evaluate client needs, its own solutions and the solutions of competitors. If top management chooses coopetition,

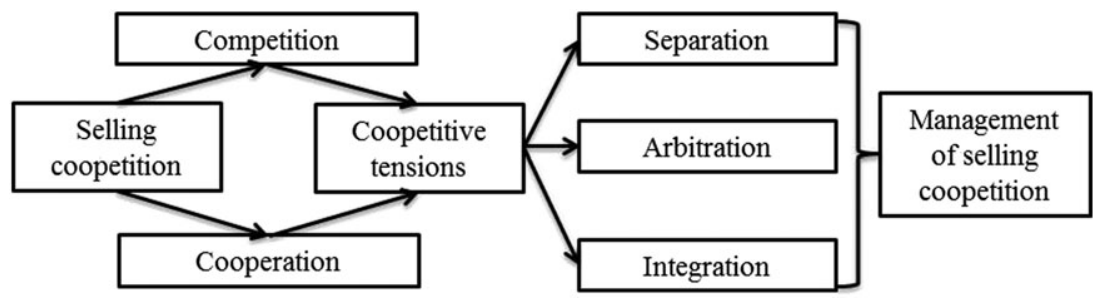

Figure 4 Key principles to manage selling coopetition 
Table 5 Separation, integration and arbitration in selling coopetition

\begin{tabular}{llll}
\hline Management Strategy & Separation & Integration & Arbitration \\
\hline Principles & $\begin{array}{l}\text { Organizational separation } \\
\text { Role repartition } \\
\text { Spatial separation }\end{array}$ & Individual integration of opposite dimensions & $\begin{array}{c}\text { Arbitrage of Top Management } \\
\text { in internal conflict }\end{array}$ \\
Managerial procedures & Alliance managers & Formalization/Guidelines/ & Arbitration a priori \\
& Formalization & Training/Communication & Arbitration a posteriori \\
Key factors & Organizational design & Organizational education & Hierarchic choice \\
Degree of uncertainty & Very low & Personal factors & Very High \\
Advantages & Simplicity & Medium & Resolution of conflict \\
& Elimination of contradictions & Reactivity & Facility of Adjustment \\
Limits & Separation cannot be complete & Difficulty to integrate both dimensions & Temporary resolution of conflict \\
& Creation of internal conflict & One dimension is neglected to focus on the & Feeling of injustice \\
\end{tabular}

revenue decreases as a result of its own solution in order to win the call for tender by offering the client the best solution combined with the best solution from the coopetitor. This stressful decision exerts pressure on top management as well as on sales people and alliance managers.

As R\&D coopetition and selling coopetition differ, it seems necessary to investigate them separately. Specific studies are needed to better understand selling coopetition in its context. This strategy involves major organizational challenges. As customers increasingly seek coopetition to obtain the best technology from each coopetitor, it is important to determine how firms should implement this strategy and adapt their managerial processes. More broadly, additional studies are needed to understand coopetition and its management in activities close to the market, such as marketing, distribution and sales (Peng and Bourne, 2009; Kylänen and Mariani, 2012, 2014; Pellegrin-Boucher et al., 2013; Chiambaretto and Dumez, 2016; Chiambaretto et al., 2016; Mariani, 2016).

\section{Conclusion}

This study is dedicated to investigating the management of selling coopetition. Past studies on coopetition management have focused on $R \& D$ coopetition, which is quite different from selling coopetition. Therefore, studies highlighting the principles used by firms to manage selling coopetition are needed. Accordingly, we built on past studies dedicated to coopetition management to design a theoretical framework in order to study selling coopetition management in the ERP and business solutions industry.

Our results indicate that firms simultaneously use three principles: separation, integration and hierarchic arbitration. We show that the separation principle is used by firms to implement a selling coopetitive strategy. We also show that if the separation principle is applied in isolation, it can create internal conflicts and tensions.
The integration principle is therefore necessary to avoid these internal conflicts. Nevertheless, we show that the integration of the coopetitive paradox by alliance managers and sales people cannot be complete. Thus, given a permanent conflict of interest between alliance managers and sales people, firms and their top management must adopt an additional principle of coopetition management - arbitration.

\section{Theoretical contributions}

Our study makes a threefold original contribution to knowledge. The first contribution concerns the management of selling coopetition. Based on our results, we posit that the management of selling coopetition requires a dynamic combination of two principles already identified in the literature, separation and integration, as well as a new principle identified in this study arbitration. Second, this research contributes to knowledge on coopetition management. Existing knowledge has mainly focused on $R \& D$ coopetition. We fill the gap in the knowledge by showing that some management principles are similar and others are different. Finally, we contribute to coopetition theory by increasing knowledge of coopetition in activities directly linked to the market as selling activities.

\section{Managerial contributions}

We identify operational procedures applied to manage selling coopetition that have relevance for practitioners. Top managers should attempt to separate competition and cooperation within the structure and functioning of their firm. Simultaneously, at the individual level, managers should attempt to integrate the paradoxical nature of coopetition by using guidelines, discourses and training support provided by the top management team. However, because these two principles applied together are not sufficient, managers must also design and implement an arbitration process that facilitates the 
reduction/resolution of the inevitable conflicts of interest that manifest internally.

\section{Limitations and future research}

The limitations of our study are determined by the complexity of the researched topic and by its exploratory approach. Notably, this study cannot and does not provide an exhaustive list of principles or managerial procedures that can be automatically applied in any coopetitive situation. Only the specific structure and context of each coopetitive partnership can provide the basis for developing and applying the best-adapted paradox management strategy. From this perspective, the limitations of the present study are identified.

First, the qualitative methodology applied in this study restricts the possibility of generalizing the findings. Future research should therefore qualitatively and quantitatively investigate the relevance of our findings in order to validate and refine them. Second, we exclusively focused on ICT firms, although coopetition is frequently encountered in other industries. The specificity of the sector and market might specifically shape both coopetitive agreements and their management at organizational and individual levels. Considering the specificity of various industrial sectors, future projects should adopt a comparative approach to understand how industry characteristics influence the application of managerial principles and procedures for coopetitive selling.

Third, the management of selling coopetitive agreements is a process that is developed over time, which can be considered a dynamic capability of an organization. To understand the factors that facilitate its organizational development and diffusion, future studies must mobilize such concepts as organizational and managerial learning to analyse and explain the evolution of firms' coopetition management capability.

Finally, future studies should investigate the evolution of management procedures in various stages of coopetition projects and the new tensions introduced within and between organizations by these coordinating elements. These topics constitute a research project that is applicable to the entire value-added chain (i.e., supply, $\mathrm{R} \& \mathrm{D}$, manufacturing, and marketing). Our study is one step in a global project of understanding coopetition management.

\section{Acknowledgement}

The authors are members of the LabEx Entrepreneurship, Montpellier, France. This "Laboratory of Excellence" is part of a French government fund recognizing and promoting performing research initiatives in human and natural sciences.

\section{References}

Arthur, B. W., 1989, "Competing technologies, increasing returns, and lock-in by historical events". Economic Journal, 99: 116-132.

Arthur, B. W., 1994, Increasing returns and path dependence in the economy. Ann Arbor, MI: University of Michigan Press.

Bengtsson, M., J. Eriksson and L. Wincent, 2010, "New ideas for a new paradigm". In Yami S., S. Castaldo, G. B. Dagnino and F. Le Roy (eds.), Coopetition: Winning strategies for the 21st century. Cheltenham: Edward Elgar, pp. 19-39.

Bengtsson, M. and S. Kock, 1999, "Cooperation and competition in relationships between competitors in business networks". Journal of Business and Industrial Marketing, 14: 178-190.

Bengtsson, M. and S. Kock, 2000, "Coopetition' in business networks - To cooperate and compete simultaneously". Industrial Marketing Management, 5: 411-426.

Bengtsson, M. and S. Kock, 2014, "Coopetition - Quo vadis? Past accomplishments and future challenges". Industrial Marketing Management, 43: 180-188.

Bouncken, R., T. Clauß and V. Fredrich, 2016, "Product innovation through coopetition in alliances: Singular or plural governance?" Industrial Marketing Management, 53: 77-90.

Bouncken, R. B. and V. Fredrich, 2012, "Coopetition: Performance implications and management antecedents". International Journal of Innovation Management, 16: 1-28.

Bouncken, R. B. and S. Kraus, 2013, "Innovation in knowledgeintensive industries: The double-edged sword of coopetition". Journal of Business Research, 66: 2060-2070.

Brandenburger, A. and B. Nalebuff, 1996, Co-opetition. New York: Doubleday.

Capasso, A. and G. B. Dagnino, 2014, "Beyond the 'silo view' of strategic management and corporate governance: Evidence from fiat, Telecom Italia and Unicredit". Journal of Management \& Governance, 18: 929-957.

Chen, M. J., 2008, "Reconceptualizing the competitioncooperation relationships". Journal of Management Inquiry, 20: $1-19$.

Chiambaretto, P. and H. Dumez, 2016, "Toward a typology of coopetition: A multilevel approach". International Studies of Management and Organization, 46: 110-129.

Chiambaretto, P., C. Gurau and F. Le Roy, 2016, "Coopetitive branding: Definition, typology, benefit and risks". Industrial Marketing Management, 57: 86-96.

Chonko, L. B., 1999, "Alliance formation with direct selling companies: The case of Avon and Mattel". Journal of Personal Selling and Sales Management, 19: 51-62.

Clarke-Hill, C., H. Li and B. Davies, 2003, "The paradox of cooperation and competition in strategic alliances: Towards a multi-paradigm approach". Management Research News, 26: $1-21$.

Contractor, F.-J. and P. Lorange, 2002, "The growth of alliances in the knowledge-based economy". International Business Review, 4: 485-503.

Czakon, W. and K. Czernek, 2016, "The role of trust-building mechanisms in entering into network coopetition: The case of tourism networks in Poland". Industrial Marketing Management, 57: 64-74.

Czakon, W., K. Mucha-Kuś and M. Rogalski, 2014, "Coopetition research landscape - A systematic literature 
review 1997-2010". Journal of Economics \& Management, 17: 122-150.

Dagnino, G. B., M. C. Di Guardo and G. Padula, 2012, "Coopetition: Nature, challenges, and implications for firms' strategic behavior and managerial mindset". In Dagnino G. B. (ed.), Handbook of research on competitive strategy. Cheltenham: Edward Elgar, pp. 492-511.

Dowling, M. J., W. D. Roering, B. A. Carlin and J. Wisnieski, 1996, "Multifaceted relationships under coopetition". Journal of Management Inquiry, 2: 155-167.

Dussauge, P., B. Garrette and W. Mitchell, 2000, "Learning from competing partners: Outcome and durations of scale and link alliances in Europe, North America and Asia". Strategic Management Journal, 21: 99-126.

Eisenhardt, K. M., 1989, "Building theories from case study research". Academy of Management Review, 14: 532-550.

Estrada, I., D. Faems and P. de Faria, 2016, "Coopetition and product innovation performance: The role of internal knowledge sharing mechanisms and formal knowledge protection mechanisms". Industrial Marketing Management, 53: $56-65$.

Fernandez, A.-S. and P. Chiambaretto, 2016, "Managing tensions related to information in coopetition". Industrial Marketing Management, 53: 66-76.

Fernandez, A.-S., F. Le Roy and D. Gnyawali, 2014, "Sources and management of tension in coopetition case evidence from telecommunications satellites manufacturing in Europe". Industrial Marketing Management, 2: 222-235.

Fjeldstad, Ø. D., M. Becerra and S. Narayanan, 2004, "Strategic action in network industries: An empirical analysis of the European mobile phone industry". Scandinavian Journal of Management, 20: 173-197.

Gibbert, M., W. Ruigrok and B. Wicki, 2008, "What passes as a rigorous case study?" Strategic Management Journal, 29: 1465-1474.

Glaser, B. and A. Strauss, 1967, The discovery grounded theory: Strategies for qualitative inquiry. Chicago, IL: Aldin.

Gnyawali, D. R., J. He and R. Madhavan, 2008, "Co-opetition promises and challenges". In Wankel C. (ed.), The 21st century management: A reference handbook Vol. 38. Los Angeles, CA: Sage Publications, pp. 386-398.

Gnyawali, D. R. and B. J. Park, 2009, "Co-opetition and technological innovation in small and medium-sized enterprises: A multilevel conceptual model". Journal of Small Business Management, 47: 308-330.

Gnyawali, D. R. and B. J. Park, 2011, "Co-opetition between giants: Collaboration with competitors for technological innovation". Research Policy, 40: 650-663.

Hallikas, J., J. Levy, P. Ritala and H. Sissonen, 2006, "Competitive and cooperative networks in the ICT sector to indicate the level of coopetition". Paper presented at the 2nd Workshop on Coopetition Strategy, September, Milan.

Hamel, G., 1991, "Competition for competence and interpartner learning within international strategic alliances". Strategic Management Journal, 12: 83-104.

Harryson, S. J., R. Dudkowski and A. Stern, 2008, "Transformation networks in innovation alliances - The development of Volvo C70". Journal of Management Studies, 45: 745-773.
Herzog, T., 2010, "Strategic management of coopetitive relationships in CoPS-related industries". In Yami S., S. Castaldo, G. B. Dagnino and F. Le Roy (eds.), Coopetition: Winning strategies for the 21st century. Cheltenham: Edward Elgar, pp. 200-215.

Jones, E., L. B. Chonko and J. A. Roberts, 2003, "Creating a partnership-oriented knowledge oriented culture in strategic sales alliances: A conceptual framework". Journal of Business and Industrial Marketing, 18: 336-349.

Katz, M. L. and C. Shapiro, 1994, "Systems competition and network effects". Journal of Economic Perspectives, 8: 93-116.

Kylänen, M. and M. M. Mariani, 2012, "Unpacking the temporal dimension of coopetition in tourism destinations: Evidence from Finnish and Italian theme parks". Anatolia: An International Journal of Tourism and Hospitality Research, 23: 61-74.

Kylänen, M. and M. M. Mariani, 2014, "Cooperative and coopetitive practices: Cases from the tourism industry". In Mariani M. M., R. Baggio, D. Buhalis and C. Longhi (eds.), Tourism management, marketing, and development. Volume I: The importance of networks and ICTs. New York: Palgrave, pp. 149-178.

Le Roy, F. and W. Czakon, 2016, "Managing coopetition: The missing link between strategy and performance". Industrial Marketing Management, 53: 3-6.

Le Roy, F. and A. S. Fernandez, 2015, "Managing coopetitive tensions at the working-group level: The rise of the coopetitive project team". British Journal of Management, 26: 671-688.

Le Roy, F., M. Robert and F. Lasch, 2016, "Choosing the best partner for product innovation: Talking to the enemy or to a friend?" International Studies of Management and Organization, 46: 136-158.

Lundgren-Henriksson, E.-L. and S. Kock, 2016, "Coopetition in a headwind - The interplay of sensemaking, sensegiving, and middle managerial emotional response in coopetitive strategic change development". Industrial Marketing Management, 58: 20-34.

Luo, X., A. Rindfleisch and D. K. Tse, 2007, "Working with rivals: The impact of competitor alliances on financial performance". Journal of Marketing Research, 44: 73-83.

Mariani, M. M., 2016, "Coordination in inter-network coopetitition: Evidence from the tourism sector". Industrial Marketing Management, 53: 103-123.

Miles, B. and M. Huberman, 1994, Qualitative data analysis: A source book of new methods. London: Sage Publications.

O'Brien, E. and C. Linehan, 2014, "A balancing act: Emotional challenges in the HR role". Journal of Management Studies, 8 : 1257-1285.

Oliver, A. L., 2004, "On the duality of competition and collaboration: Network-based knowledge relations in the biotechnology industry". Scandinavian Journal of Management, 20: 151-171.

Oracle Financial Services, 2015, "Oracle Financial Services Software Limited: Annual report". Available from http://www. oracle.com/us/industries/financial-services/ofssl-annual-report2014-15-2628306.pdf. Accessed 22 April 2017.

Oshri, I. and C. Weber, 2006, "Cooperation and competition standards-settings activities in the digitization area: The case 
of wireless information devices". Technology Analysis \& Strategic Management, 2: 265-283.

Padula, G. and G. Dagnino, 2007, "Untangling the rise of coopetition: The intrusion of competition in a cooperative game structure". International Studies of Management \& Organization, 37: 32-52.

Park, B. S., M. K. Srivastava and D. R. Gnyawali, 2014, "Walking the tight rope of coopetition: Impact of competition and cooperation intensities and balance on firm innovation performance". Industrial Marketing Management, 43: 210-221.

Pellegrin-Boucher, E., F. Le Roy and C. Gurău, 2013, "Coopetitive strategies in the ICT sector: Typology and stability”. Technology Analysis \& Strategic Management, 25: 71-89.

Peng, T.-J. A. and M. Bourne, 2009, “The coexistence of competition and cooperation between networks: Implications from two Taiwanese healthcare networks". British Journal of Management, 20: 377-400.

Peng, T. A., S. Pike, J. C. Yang and G. Roos, 2012, "Is cooperation with competitors a good idea? An example in practice". British Journal of Management, 23: 532-560.

PwC, 2014, "Global software top 100"; Available from http:// www.pwc.com/gx/en/technology/publications/global-software100-leaders/assets/pwc-global-100-software-leaders-2014.pdf. Accessed 21 September 2015.

Quintana-García, C. and C. A. Benavides-Velasco, 2004, "Cooperation, competition, and innovative capability: A panel data of European dedicated biotechnology firms". Technovation, 24: 927-938.

Raza-Ullah, T., M. Bengtsson and S. Kock, 2014, "The coopetition paradox and tension in coopetition at multiple levels". Industrial Marketing Management, 43: 189-198.

Ritala, P., 2012, "Coopetition strategy - When is it successful? Empirical evidence on innovation and market performance". British Journal of Management, 23: 307-324.

Ritala, P. and P. Hurmelinna-Laukkanen, 2009, "What's in it for me? Creating and appropriating value in innovationrelated coopetition". Technovation, 29: 819-828.

Ritala, P., S. Kraus and R. Bouncken, 2016, "Introduction to coopetition and innovation: Contemporary topics and future research opportunities". International Journal of Technology Management, 71: 1-9.
Ritala, P. and L. Sainio, 2014, "Coopetition for radical innovation: Technology, market and business-model perspectives". Technology Analysis \& Strategic Management, 26: $155-169$.

SAP, 2015, "Reimagine your business: 2015 annual report"; Available from http://go.sap.com/docs/download/investors/2015/ sap-2015-annual-report.pdf; 2015. Accessed 22 April 2017.

Seran, T., E. Pellegrin-Boucher and C. Gurau, 2016, "The management of coopetitive tensions within multi-unit organizations". Industrial Marketing Management, 53: 31-41.

Shapiro, C. and H. Varian, 1999, Information rules: A strategic guide to the network economy. Boston, MA: Harvard Business Press.

Skaates, M. A. and H. Tikkanen, 2003, "International project marketing: An introduction to the INPM approach". International Journal of Project Management, 21: 503-510.

Smith, W. K. and M. W. Lewis, 2011, "Toward a theory of paradox: A dynamic equilibrium model of organizing". Academy of Management Review, 2: 381-403.

Stadtler, L. and L. N. Van Wassenhove, 2016, "Coopetition as a paradox: Integrative approaches in a multi-company, crosssector partnership". Organization Studies, 37: 655-685.

Strauss, A. and J. Corbin, 1998, Basics of qualitative research: Techniques and procedures for developing grounded theory, 2nd ed. Thousand Oaks, CA: Sage.

Taylor, A., 2005, "An operations perspective on strategic alliance success factors: An exploratory study of alliance managers in the software industry". International Journal of Operations and Production Management, 25: 469-489.

Tidström, A., 2013, "Managing tensions in coopetition". Industrial Marketing Management, 43: 261-271.

Troesch, E. M. and P. F. Schikora, 2010, "Co-opetition between SAP and Oracle: The effects of the partnership and competition on the companies' success". Journal of Business Case Studies, 6: 59-65.

Yami, S., S. Castaldo, G. B. Dagnino and F. Le Roy, 2010, Coopetition: Winning strategies for the 21st century. Cheltenham: Edward Elgar Publishing.

Yin, R. K., 2013, Case study research: Design and methods. London: Sage. 


\section{Appendix 1: the interview framework and coding}

\begin{tabular}{|c|c|c|c|c|}
\hline Questions & $\begin{array}{l}\text { Selling } \\
\text { coopetition }\end{array}$ & $\begin{array}{l}\text { Separation/ } \\
\text { Integration }\end{array}$ & Management procedures & Coding \\
\hline $\begin{array}{l}\text { What are the types of } \\
\text { selling agreements } \\
\text { done with your } \\
\text { partners? }\end{array}$ & $\begin{array}{l}\text { Selling with partners vs } \\
\text { Selling alone } \\
\text { Types }\end{array}$ & $\begin{array}{l}\text { Sales people sell alone } \\
\text { Alliance managers sell } \\
\text { with partners }\end{array}$ & $\begin{array}{l}\text { Formal agreements } \\
\text { Lawyers } \\
\text { Dyadic relationships }\end{array}$ & $\begin{array}{l}\text { Selling alliances } \\
\text { and partnerships } \\
\text { Calls for tenders } \\
\text { Alone/together } \\
\text { Exclusivity deals } \\
\text { Formal and dyadic }\end{array}$ \\
\hline $\begin{array}{l}\text { How do you manage } \\
\text { cooperation with } \\
\text { your partners? }\end{array}$ & $\begin{array}{l}\text { Networks, influence, } \\
\text { events } \\
\text { Training, Support }\end{array}$ & $\begin{array}{l}\text { Only alliance } \\
\quad \text { managers }=> \\
\text { separation }\end{array}$ & $\begin{array}{l}\text { Formal and informal } \\
\text { procedure }\end{array}$ & $\begin{array}{l}\text { Formal and informal } \\
\text { Alliance manager } \\
\text { Separations }\end{array}$ \\
\hline $\begin{array}{l}\text { How do you manage } \\
\text { cooperation with } \\
\text { competitors? }\end{array}$ & $\begin{array}{l}\text { The same + separation } \\
\text { and more tensions. } \\
\text { Less alliances }\end{array}$ & $\begin{array}{l}\text { Separation in the case } \\
\text { of sales people and } \\
\text { alliance managers }\end{array}$ & $\begin{array}{l}\text { Role functions } \\
\text { Not with all competitors }\end{array}$ & $\begin{array}{l}\text { Separation } \\
\text { Limits } \\
\text { Tensions }\end{array}$ \\
\hline $\begin{array}{l}\text { How do you evaluate } \\
\text { the success of } \\
\text { selling alliances? }\end{array}$ & $\begin{array}{l}\text { Technical/software } \\
\text { tools } \\
\text { Turn over }\end{array}$ & Separation & $\begin{array}{l}\text { More quantitative tools } \\
\text { than qualitative } \\
\text { (satisfaction study) }\end{array}$ & $\begin{array}{l}\text { Software } \\
\text { Turn over } \\
\text { Satisfaction } \\
\text { Separation }\end{array}$ \\
\hline $\begin{array}{l}\text { Do you receive some } \\
\text { guidelines or advice } \\
\text { concerning } \\
\text { situations of } \\
\text { coopetition? }\end{array}$ & $\begin{array}{l}\text { Internal and global } \\
\text { guidelines from the } \\
\text { strategy department } \\
\text { towards managers }\end{array}$ & $\begin{array}{l}\text { Guidelines insist on } \\
\text { the necessity of } \\
\text { coopetition } \\
\text { But also explain } \\
\text { separation }\end{array}$ & $\begin{array}{l}\text { Guidelines } \\
\text { Communication } \\
\text { Arbitrage from } \mathrm{N}+1\end{array}$ & $\begin{array}{l}\text { Integration } \\
\text { Guidelines } \\
\text { Separation } \\
\text { Arbitration } \\
\text { Guidelines }\end{array}$ \\
\hline $\begin{array}{l}\text { How are the partners } \\
\text { managed and } \\
\text { considered? }\end{array}$ & $\begin{array}{l}\text { Ecosystem of partners } \\
\text { allows to win new } \\
\text { markets }\end{array}$ & $\begin{array}{l}\text { Separation: the alliance } \\
\text { managers coordinate } \\
\text { partners, not the } \\
\text { sales people }\end{array}$ & $\begin{array}{l}\text { On a weekly basis } \\
\text { Formal and informal } \\
\text { tools } \\
\text { Difficult to measure the } \\
\text { influence }\end{array}$ & $\begin{array}{l}\text { Role of alliance } \\
\quad \text { managers } \\
\text { Role of partners } \\
\text { Separation } \\
\text { Limits }\end{array}$ \\
\hline $\begin{array}{l}\text { How are the coopetitors } \\
\text { managed and } \\
\text { considered in your } \\
\text { company? }\end{array}$ & $\begin{array}{l}\text { More touchy } \\
\text { Some alliances fail }\end{array}$ & $\begin{array}{l}\text { Separation and } \\
\text { integration } \\
\text { Arbitration when it is } \\
\text { not sufficient }\end{array}$ & $\begin{array}{l}\text { Possibility to stop an } \\
\text { alliance: arbitration } \\
\text { Failure of alliances } \\
\text { when competition is } \\
\text { too strong }\end{array}$ & $\begin{array}{l}\text { Limits } \\
\text { Separation, and } \\
\quad \text { integration not } \\
\quad \text { sufficient } \\
\text { Arbitration } \\
\text { Failure of alliances }\end{array}$ \\
\hline $\begin{array}{l}\text { Do you feel tensions } \\
\text { within your } \\
\text { organisation? }\end{array}$ & $\begin{array}{l}\text { Tensions between } \\
\text { business units and } \\
\text { between salespeople } \\
\text { and alliance managers }\end{array}$ & $\begin{array}{l}\text { Separation and } \\
\text { integration not } \\
\text { sufficient }\end{array}$ & $\begin{array}{l}\text { Arbitration } \\
\text { Integration } \\
\text { Arbitration }\end{array}$ & $\begin{array}{l}\text { Conflicts of interests } \\
\text { Tensions } \\
\text { Arbitration } \\
\text { Integration and } \\
\quad \text { separation not } \\
\text { sufficient }\end{array}$ \\
\hline $\begin{array}{l}\text { Do you feel tensions } \\
\text { with your partners? }\end{array}$ & $\begin{array}{l}\text { Tensions felt by the } \\
\text { alliance managers with } \\
\text { some competitors that } \\
\text { don't trust them }\end{array}$ & $\begin{array}{l}\text { Separation and } \\
\text { integration not } \\
\text { sufficient }\end{array}$ & $\begin{array}{l}\text { Tensions when } \\
\text { competitors: depends } \\
\text { on the people and on } \\
\text { the firms strategies }\end{array}$ & $\begin{array}{l}\text { Separation and } \\
\text { integration not } \\
\text { sufficient } \\
\text { Lack of trust }\end{array}$ \\
\hline $\begin{array}{l}\text { What is your position } \\
\text { in the company? } \\
\text { Could you please tell } \\
\text { us your daily } \\
\text { activities? }\end{array}$ & Definition of function & $\begin{array}{l}\text { Separation and } \\
\text { integration } \\
\text { Arbitration }\end{array}$ & $\begin{array}{l}\text { Daily activities, career, } \\
\text { current position } \\
\text { Arbitration }\end{array}$ & $\begin{array}{l}\text { Separation } \\
\text { Integration } \\
\text { Arbitration } \\
\text { Cooperation } \\
\text { Competition }\end{array}$ \\
\hline
\end{tabular}




\title{
Appendix 2: the operational integration of coopetition in large groups
}

\author{
Extract from guidelines
}

First, it is necessary to promote in priority the offers including only our products and services, in comparison with the offers including elements produced by our partners.

Second, it is necessary in every situation to maximize the volume and value of our sales. Our employees must understand that our main objective is to optimize our sales, and not those of our partners.

Third, from a communication point of view, we should never give priority to the offer of a competitor. The company must avoid declarations or press releases that may suggest that we promote the offer of a competitor, especially when there is also an internal offer available.

Fourth, it is important to help our coopetitor to sell the solutions offered by our company. In a coopetitive situation, the company should attempt to provide the necessary training, documentation and assistance to our competitors, in order to facilitate their task of selling our solutions.

Fifth, it is necessary to avoid exclusivity deals. A collaborative project should rarely be exclusive, in order to maintain the value of the other partnerships and permit the development of multiple alliances and/or partnerships related to the same commercial offer.

Sixth, it is essential to maintain our competitive stance. Despite the need to develop coopetitive offers, we should continue to maintain our own competitive offer.

\section{Appendix 3: integration of selling coopetition at organizational level}

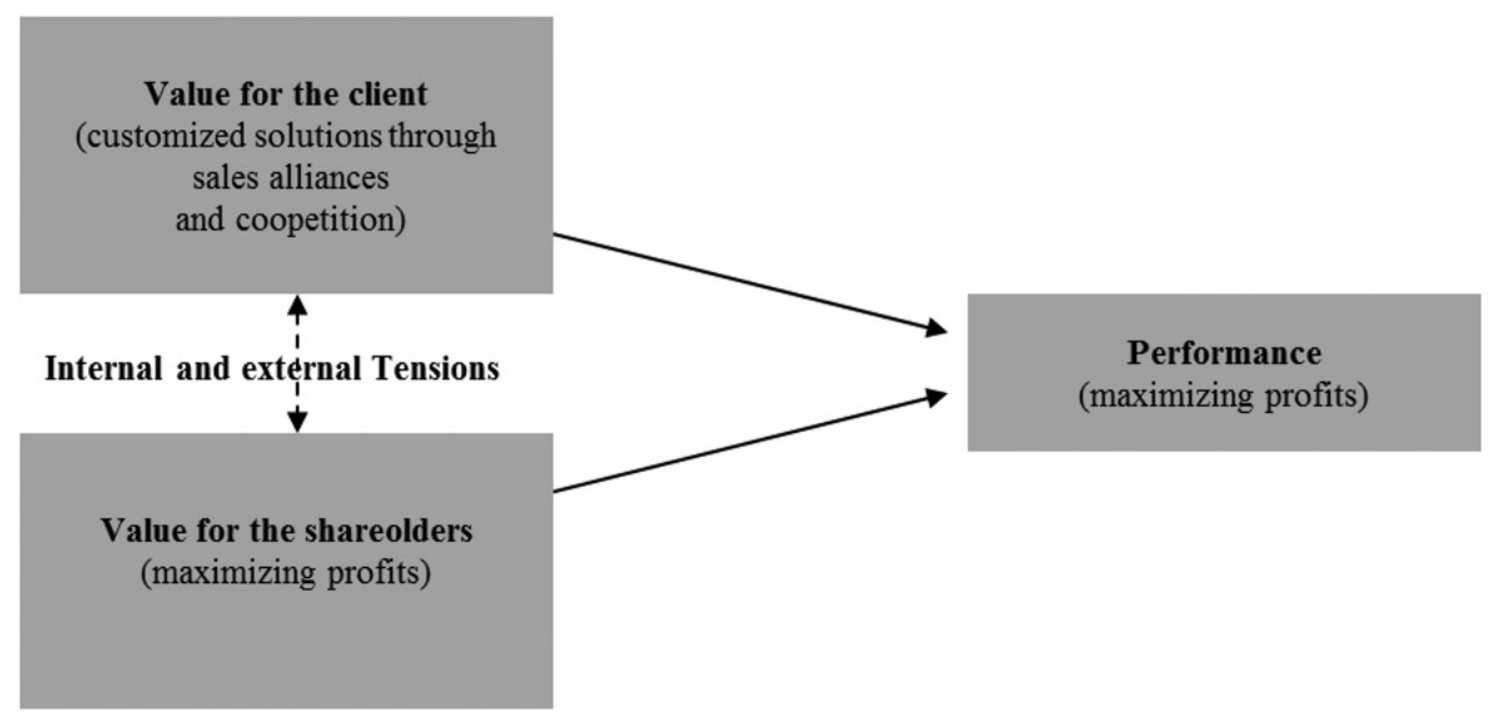

Source: IBM internal guide. 


\section{Appendix 4: interview quotations}

\begin{tabular}{lll}
\hline Quote & Interview quotations & Who \\
\hline 1 & 'When competing firms have integrated your elements into the design of their own products, they are not going & IBM alliance manager \\
& to dismiss you unless you make a very serious mistake'. & \\
& 'Our role is to cooperate with partners. Naturally, there is also some competition, but we try to put it aside and & Oracle alliance manager \\
& to activate the complementarities which can exist between our firms, not the rivalries'. & IBM salesman \\
3 & 'We prefer to make exclusive deals with only IBM products. It is normal: we are paid for that'. & IBM alliance manager \\
4 & 'It seems quite natural to be at the same time competitor and partner, because these dimensions are divided and & \\
& there is no interaction between them. Often we are in the same room with the representatives of several & Oracle Alliance manager \\
5 & competing firms, but we perceive them mainly as partners'. & IBM alliance manager \\
6 & 'IBM is an important competitor of our company, but we, in our activity, we are partners'. & SAP \\
7 & 'Our companies are competitors, but us (Mr. Y and Mr. Z), we are partners'. & alliance manager
\end{tabular}

consumer choice [...]. For us, it is important that our partner tries to influence the client. To do this properly, we attempt to inform well our partner about our company, to explain the use of our products, and sometimes to provide important intelligence data either about our firm (functioning, contacts, statistics, etc.) or about existing market opportunities'.

8 'When competing firms decide to collaborate, trust cannot be immediately developed; the other organization is first perceived as a rival, and this increases the difficulty of working together'.

9 'During informal social events, the exchanges between me and Mr. X are more open and relaxed. I take advantage of these occasions to present to him the main people of our firm - key account managers, directors, IT architects, etc., anybody who can have potential value for our alliance'.

'Since the objective of our partnership is to increase our sales, in a successful alliance, the partners will communicate about new market opportunities. It is important to develop mutual trust, so that the partner company will work with us rather than with another organization. Developing trust, we can eventually get over the conflicting interests that may exist between our companies'.

'This relationship is particularly important when we deal with developers, since the final objective is to become integrated upstream of the client's value chain'.

12 'Our firms fight very hard in some markets, but meanwhile we [the two alliance managers representing the competing firms] are developing one of the most solid alliances from the French market'.

13 'I am in charge of selling infrastructure solutions to the consulting agencies that are our company's partners, but it is almost impossible since we represent their main service competitors. This explains why, although our solutions are attractive, they are not going to apply them'.

'These guidelines were created to help the employees of the group understand the actions and behaviors which allow our company to take into account various needs (...) The following examples illustrate the specificities of these guidelines and clarify the strategic choices taken by the group' (Extract from the IBM Coopetition Guide).

'I do not think that many persons consult these guidelines. On the other hand, the spirit of these guidelines is alive; I find here principles which are effectively applied'.

'We shall always remain both partners and competitors - this is the difficulty of the job'; 'Sales people must sell alone, and we have to sell with partners; our interests are opposite, and it is impossible to reconcile them'.

'There is coopetition with service providers such as Cap Gemini, Accenture, ATOS, since they are competitors of IGS (IBM Global Services), but they also integrate in their offer IBM hardware and middleware elements. The Server and Software divisions consider these companies as partners and develop joint projects, sometimes entering into conflict with IGS or with the IBM sales force. For example, a commercial agent attached to the manufacturing division has Renault as a client; he develops with IGS a project of Business Intelligence. However, by doing this, he can enter into direct competition with Cap Gemini, which works with IBM Software agents to propose IBM middleware to the same client. In this situation, Renault may ask the IBM management team to arbitrate between the two IBM divisions which came into conflict'.

'When we cannot be in agreement inside the firm because selling people want to respond alone to the call for market and we want to respond with a partner, the manager of the SB chooses arbitration and decides if we go it alone or with the partner'.

'When there are two projects to sell a solution to a client, one alone and one with partners, I sometimes have to arbitrate and sometimes not. There are no general rules: it depends on the context, the client, the partner, the sales people, etc.'.

20 'Once I won an offer for a big client with one of my partners, and it was against someone from my company who had only proposed IBM solutions'. 